\title{
Feed restriction since lactation has reduced anxiety in adult Wistar rats
}

\section{A restrição alimentar desde a lactação reduziu a ansiedade em ratos Wistar adultos}

\section{Objective}

To evaluate the effects of macronutrients (protein, carbohydrate and/or lipid) in the diet of young adult (72 days) and adult (182 days) Wistar rats treated ad libitum and with 30\% restriction from birth on anxiety in the elevated plus-maze.

\section{Methods}

We used 238 rats treated from birth, composing the groups: Control, Protein, Carbohydrate, Lipid, Carbohydrate and Lipid, Control Restriction, Protein Restriction, Carbohydrate Restriction, Lipid Restriction and Carbohydrate and Lipid Restriction. The animals were weighed at the beginning and at the end of the experiment and tested in the elevated plus-maze. Data were submitted to analysis of variance, followed by the Newman-Keuls Test $(p<0.05)$.

\section{Results}

Among the animals treated ad libitum, the Control, Carbohydrate plus Lipid and Lipid gained more weight than the Carbohydrate and Protein; ad libitum animals gained more weight than those on restriction; among the restrictions, Carbohydrate Restriction rats were the ones that gained less weight. Diet-restricted animals exhibited reduced first-entry latency, greater percentage of entries and time spent, frequency of open arm extremity visits, head dipping (protected and unprotected), and length of stay in the central area of the elevated

\footnotetext{
1 Universidade Federal dos Vales do Jequitinhonha e Mucuri, Faculdade de Ciências Biológicas e da Saúde, Departamento de Nutrição. Rod. MGT 367, Km 583, n 5000, Campus JK, Alto da Jacuba, 39100-000, Diamantina, MG, Brasil. Correspondence to: TR RIUL. E-mail: <taniriul@yahoo.com.br>.

2 Universidade de São Paulo, Faculdade de Filosofia, Ciências e Letras de Ribeirão Preto, Departamento de Psicologia. Ribeirão Preto, SP, Brasil.

Support: Conselho Nacional de Desenvolvimento Científico e Tecnológico (Process no 157838/2015-3) and Fundação de Amparo à Pesquisa do Estado de São Paulo (Process no 2016/07845-4).
}

\footnotetext{
How to cite this article

Riul TG, Almeida SS. Feed restriction since lactation has reduced anxiety in adult Wistar rats. Rev Nutr. 2020;33:e190143. http://dx.doi.org/10.1590/1678-9865202033e190143
} 
plus-maze. The animals with 182 days presented greater latency for first entry, reduced frequency of false entries and visits to the ends of the open arms and protected head dipping.

\section{Conclusion}

Food restricted animals, regardless of the macronutrient present in the diet, were less anxious and/or increased their impulsivity and those at 182 days were more anxious and/or with reduced impulsivity.

Keywords: Anxiety. Caloric restriction. Carbohydrates. Diet, high-fat. Diet, high-protein. Nutrients.

\section{R E S U M O}

\section{Objetivo}

Este estudo buscou avaliar os efeitos dos macronutrientes (proteína, carboidrato elou lipídeos) na alimentação de ratos Wistar adultos jovens (72 dias) e adultos (182 dias) tratados ad libitum e com restrição a 30\% desde o nascimento quanto à ansiedade através do labirinto em cruz elevado.

\section{Métodos}

Foram utilizados 238 ratos tratados desde o nascimento, compondo os grupos Controle, Proteína, Carboidrato, Lipídeos, Carboidrato e Lipídeos, Restrição Controle, Restrição Proteína, Restrição Carboidrato, Restrição Lipídeos e Restrição Carboidrato e Lipídeos. Os animais foram pesados no início e no final do experimento e testados no labirinto em cruz elevado. Os dados foram submetidos à análise de variância, seguida do teste de Newman-Keuls $(p<0,05)$.

\section{Resultados}

Entre os animais tratados ad libitum, os dos grupos Controle, Carboidrato e Lipídeos, e Lipídeos ganharam mais peso do que os Carboidrato e Proteína; os ad libitum ganharam mais peso do que os de restrição; os Restrição Carboidrato foram os que ganharam menos peso. Animais alimentados com restrição de dieta apresentaram menor latência de primeira entrada, maior porcentagem de entradas e de tempo gasto, frequência de visitas às extremidades dos braços abertos, de mergulho (protegido e desprotegido) e tempo de permanência na área central do labirinto em cruz elevado. Os animais com 182 dias demonstraram maior latência para primeira entrada, menor frequência de falsas entradas e visitas às extremidades dos braços abertos e mergulho protegido.

\section{Conclusão}

Os animais em restrição alimentar, independentemente do macronutriente presente na dieta, foram menos ansiosos elou mais impulsivos, e os com 182 dias foram mais ansiosos elou menos impulsivos.

Palavras-chave: Ansiedade. Restrição calórica. Carboidratos. Dieta hiperlipídica. Dieta rica em proteínas. Nutrientes.

\section{NTRODUCTION}

Data published by the United Nations Children's Fund, the World Health Organization and the World Bank [1] showed that 150.8 million (22.2\%) children under 5 years of age were malnourished and 38.3 million (5.6\%) were overweight in 2017. Early life experiences, including nutrition, play an important role in the development of an organism and early exposure to inadequate nutritional conditions can cause the development of chronic non-communicable diseases, including metabolism disorders and long-term behavioral changes $[2,3]$.

Several tests have been developed to assess anxiety in animals, including the Elevated Plus-Maze (EPM) test that generates an ethological conflict by contrasting the animals' natural tendency to explore new environments with the aversive characteristics of an open, lighted and elevated space. This conflict of approach-avoidance results in behaviors correlated with anxiety, that is, the enhanced exploration of the open arms, which is interpreted as an anxiolytic effect (reduction of anxiety) while exploration reduction is interpreted as an anxiogenic effect (anxiety increase) [4]. 
The assessment of anxiety in animals treated with obesogenic diets (rich in carbohydrates $[5,6]$, lipids [7-17] and carbohydrates and lipids [18,19]) is controversial. For some authors, the diet did not change the behavior in the EPM $[5-7,9,10,16,20]$, for others it increased $[8,11,12,14,15,17-19]$ or reduced anxiety [13].

The beneficial effects of dietary restriction are widely reported in the literature in different organic systems, including the central nervous system, with increased survival and decreased morbidity. Chronic moderate food restriction is the only known and reproducible intervention associated with increased longevity [21] demonstrated in short-lived animals [22].

Pifferi et al. [23] evaluated the effect of moderate chronic food restriction (30\%) and demonstrated that the animals showed an increased longevity, a reduction in diseases associated with aging such as cancer, preserved the white matter, but accelerated the gray matter atrophy in much of the brain, indicating a negative impact of food restriction on the integrity and functioning of the central nervous system. The results of food restriction in the EPM are as contradictory as those of excess macronutrients. While some authors found no change [24], others found a reduction [25] or an increase in anxiety [26-28].

There is a wide variation in the type and amount of nutrient (carbohydrate, lipid and protein), time of treatment and stage of life of the animals that can contribute to the outcome disparities; in addition, the understanding of how early unhealthy nutritional practices hinder the development of the central nervous system and behavior, evaluating the simultaneous role of each macronutrient (in excess and restricted) in the performance of young and adult rats is important to prevent or delay the onset of mental illnesses, such as anxiety disorders. Thus, the objective of this study was to evaluate the effects of macronutrients (protein, carbohydrate and/or lipid) in the diet of young adult (72 days) and adult (182 days) Wistar rats treated ad libitum and with 30\% restriction since birth in the elevated plus-maze.

\section{METHODS}

A total of 32 litters of Rattus novergicus (Wistar lineage) from the central bioterium of the University of São Paulo - Ribeirão Preto Campus, were used. The litters (dam with 8 male pups) were kept in polypropylene cages $(41 \times 40 \times 17 \mathrm{~cm})$, under 12-hours light-dark cycles (beginning of the light cycle at $6 \mathrm{am}$ ), temperature $21 \pm 2^{\circ} \mathrm{C}$ and natural humidity throughout the study. On the $21 \mathrm{st}$ day of age the puppies were weaned and placed in individual cages, receiving the same nutritional treatment as their mothers and water ad libitum until the end of the experiment.

The dams were discarded and only the puppies made up the study sample that included ten nutritional groups that were subdivided into two subgroups, one tested at 72 days of age and another at 182 days of age. Each group included 10 to 16 animals each, totaling 238 rats: (1) Control (C): AIN-93 diet ad libitum; (2) Protein (P): AIN-93 diet added with 30\% calories from protein (casein) ad libitum; (3) Carbohydrate (G): AIN-93 diet added with 30\% calories from simple carbohydrates (sugar) ad libitum; (4) Lipid (L): AIN-93 diet plus 30\% calories from unsaturated lipids (lard) ad libitum; (5) Carbohydrate and Lipid (GL): AIN-93 diet plus 30\% calories from simple carbohydrates (sugar) and unsaturated lipids (lard) ad libitum; (6) Restriction Control ( $\mathrm{rC}$ ): $70 \%$ of the AIN-93 diet ingested by C; (7) Protein Restriction (rP): $70 \%$ of the AIN-93 diet plus $30 \%$ calories from protein (casein) 
ingested by $\mathrm{P}$; (8) Carbohydrate Restriction ( $\mathrm{rG}$ ): $70 \%$ of the AIN-93 diet plus 30\% calories from simple carbohydrates (sugar) ingested by G; (9) Lipid Restriction ( $\mathrm{rL}$ ): $70 \%$ of the AIN-93 diet plus 30\% calories from unsaturated lipids (lard) ingested by L; and (10) Carbohydrate and Lipid Restriction (rGL): $70 \%$ of the AIN-93 diet plus 30\% calories from simple carbohydrates (sugar) and unsaturated lipids (lard) ingested by Carbohydrate and Lipid.

The diets were prepared according to AIN-93, modified [29] and their compositions are shown in Table 1. All diets were stored under refrigeration until the animals were fed (between 7 and 9 hours). Weight gain was calculated by the difference between the final weight (72 or 182 days) and the initial weight (21 days).

The animals with 72 and 182 days of life were tested in the elevated plus maze, as described by Soares et al. [29]. The Elevated Plus-Maze consists of an apparatus with two closed arms $(50 \times 10 \times 40 \mathrm{~cm})$ perpendicular to two open arms $(50 \times 10 \mathrm{~cm})$ and a central area $(10 \times 10 \mathrm{~cm})$, raised $50 \mathrm{~cm}$ from the floor of the room. A camera (Sony ${ }^{\circledR}$, Japan, Handcam model) was placed above the maze, connected to a computer ( $\mathrm{LG}^{\circledR}$, United States) with a video capture program GeoVision GV-800 System (Copyright 2006 - Multicam System/Multicam Surveillance System 8.01), installed in an adjacent room to enable the monitoring and recording of images for further assessments.

Each rat was placed in the central area with the head facing one of the closed arms and left for five minutes for free exploration. The number of entries (with the four paws) and the time spent in the open and closed arms, latency of first entry in the open arms, frequency of rearing, protected and unprotected head dipping, false entries and visits to the extremities of the open arms were recorded.

With these data at hand, the following was calculated: time in the open arms: time in the open arms/(time in the open + closed arms)x100; \% frequency of entry in the open arms; number of entries in the open arms/(number of entries in the open + closed arms) x100; time in the center; test duration (300s) - (time in the open + closed arms); total dive: protected + unprotected dive. Data on body weight gain and behavior was tested using ANOVA, with two factors: diet (with

Table 1. Centesimal composition of diets prepared according to AIN-93, modified [23]. Ribeirão Preto, Brazil, 2018.

\begin{tabular}{|c|c|c|c|c|c|}
\hline Diets & Control & Protein & Carbohydrate & Lipid & Carbohydrate and Lipid \\
\hline \multicolumn{6}{|l|}{ Ingredients } \\
\hline Casein (g) & 17.56 & 38.54 & 13.45 & 15.46 & 14.39 \\
\hline Methionine (g) & 0.04 & 0.08 & 0.03 & 0.03 & 0.03 \\
\hline Starch (g) & 68.47 & 51.00 & 52.45 & 60.28 & 56.09 \\
\hline Sugar (g) & - & - & 23.40 & - & 12.51 \\
\hline Oil (g) & 7.85 & 5.85 & 6.01 & 6.91 & 6.43 \\
\hline Lard (g) & - & - & - & 11.95 & 5.56 \\
\hline Mixed salts (g) & 4.91 & 3.66 & 3.76 & 4.32 & 4.02 \\
\hline Mixed vitamins (g) & 0.98 & 0.73 & 0.75 & 0.86 & 0.80 \\
\hline Choline (g) & 0.20 & 0.15 & 0.15 & 0.17 & 0.16 \\
\hline \multicolumn{6}{|l|}{ Composition } \\
\hline Calories (kcal) & 414.93 & 411.13 & 411.41 & 472.82 & 439.99 \\
\hline Protein (\%) & 16.97 & 37.57 & 13.11 & 13.10 & 13.11 \\
\hline Carbohydrate (\%) & 66.01 & 49.62 & 73.75 & 51.00 & 62.37 \\
\hline Lipid (\%) & 17.03 & 12.81 & 13.15 & 35.90 & 24.53 \\
\hline
\end{tabular}


10 levels: $C, P, G, L, G L, r C, r P, r G, r L$ and $r G L$ ) and age (with two levels: 72 and 182 days), followed by the Newman-Keuls Test $(p<0.05)$, after finding the normal distribution. The methodology complied with the ethical principles of animal experimentation and the project was approved by the Ethics Committee on the Use of Animals of Ribeirão Preto (Universidade de São Paulo) Medical School, registered under number 090/2017.

\section{RE S U L T S}

There was a diet effect $\left(\mathrm{F}_{(9.214)}=62.07, p<0.0001\right)$ in weight gain. Animals in groups $\mathrm{C}, \mathrm{GL}, \mathrm{L}$ and $P$ gained more weight than $G, r C, r G L, r L$ and $r P$, which in turn gained more than $r G$; the $C, G L$ and $L$ gained more weight than $P$; $L$ gained more weight than $C$. There was an interaction effect between diet and age $\left(F_{(9.214)}=7.20, p<0.0001\right)$ on weight gain. Animals in all groups gained more weight at 182 days than at 72 days of life. At 72 days, C, GL and L gained more weight than G, P and all the animals on restriction; $P$ gained more than $r G, r G L, r L$ and $r P ; G, r C, r G L, r L$ and $r P$ gained more than $r G$. At 182 days, $G L$ and $L$ gained more than $C, G$ and $P ; C$ more than $G ; r L$ more than $r C, r P$ and $\mathrm{rG} ; \mathrm{rC}, \mathrm{rGL}$ and $\mathrm{rP}$ more than $\mathrm{rG}$; all animals that received an ad libitum diet gained more weight than all animals in restriction. The animals of the $r G, r G L$ and $r P$ groups entered the EPM closed arms more often than the $C\left(F_{(9.211)}=3.74, p<0.0005\right)$ and those with 72 days more than those with 182 days of life $\left(F_{(1.211)}=71.50, p<0.0001\right)$ (Figure 1).

Animals in all food restricted groups exhibited shorter latency for first entry into one of the open arms compared with all the animals treated ad libitum $\left(\mathrm{F}_{(9.208)}=7.55, p<0,0001\right)$ (Figure 2A) and higher rate of entries $\left(F_{(9.211)}=10.86, p<0.0001\right)$ (Figure $2 B$ ) and time spent in the open arms $\left(F_{(9.211)}=13.17, p<0.0001\right)$ (Figure $\left.2 C\right)$ and higher frequency of visits to the extremities of the open arms $\left(F_{(9.208)}=14.81, p<0.0001\right)$ (Figure 2D). 182-day-old animals showed greater latency in first entry into one of the open arms $\left(F_{(1.208)}=9.65, p<0.005\right)$ (Figure $\left.2 A\right)$ and less frequency of visits to the extremities of the open arms $\left(F_{(1.208)}=5.38, p<0.05\right)$ (Figure 2D).

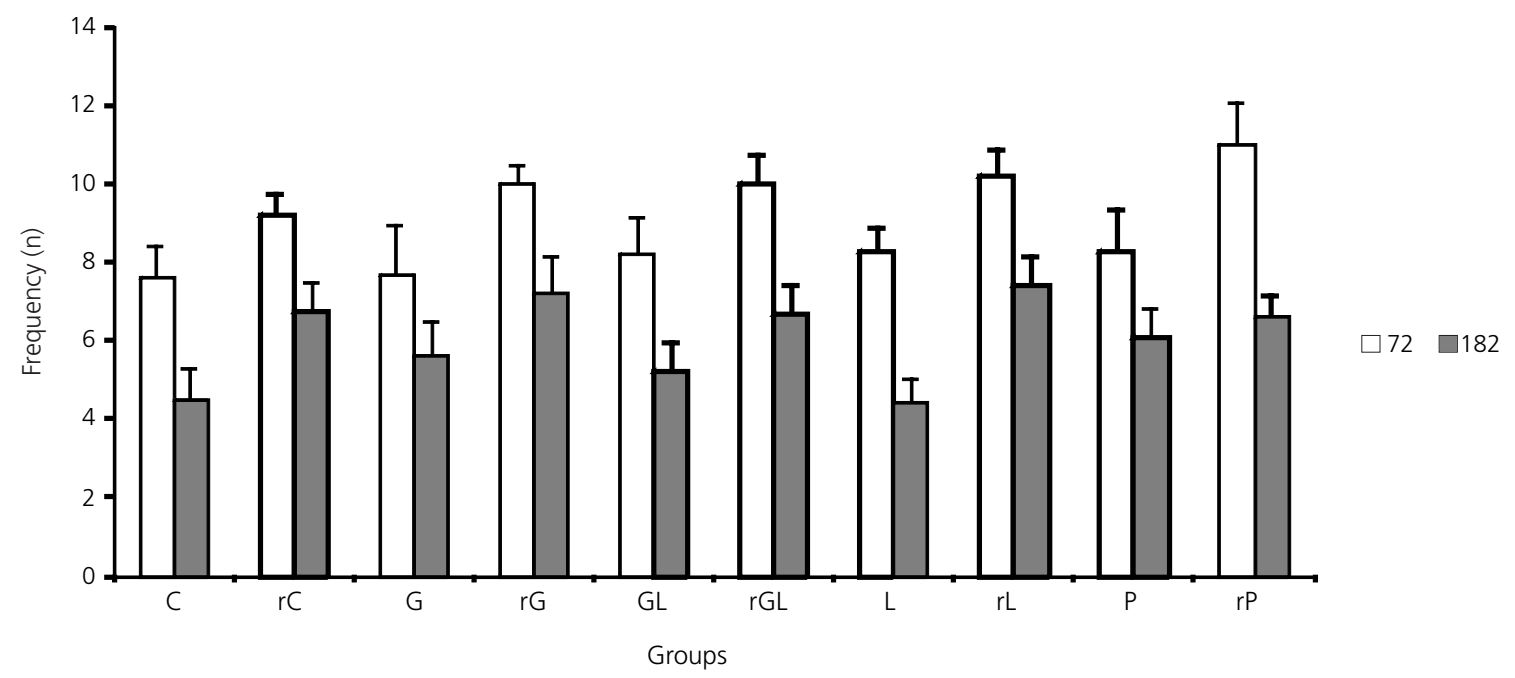

Figure 1. Frequency of entry into the closed arms of the Elevated Plus-Maze by the animals at 72 and 182 days.

Note: C: Control; G: Carbohydrate; GL: Carbohydrate and Lipid; L: Lipid; rC: Control Restriction; rG: Carbohydrate Restriction; rGL: Carbohydrate and Lipid Restriction; rL: Lipid Restriction; rP: Protein Restriction.

rG, rGL, rP>C; $72>182$, by Newman-Keuls Test $(p<0.05)$. 


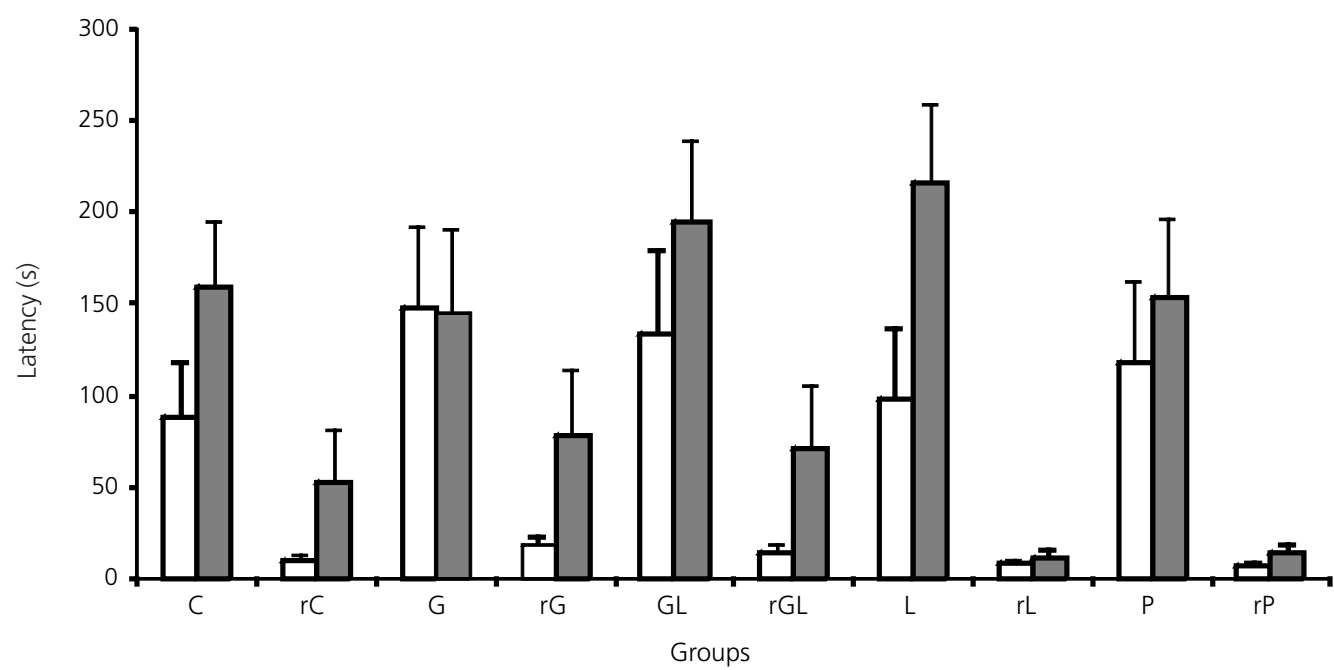

A

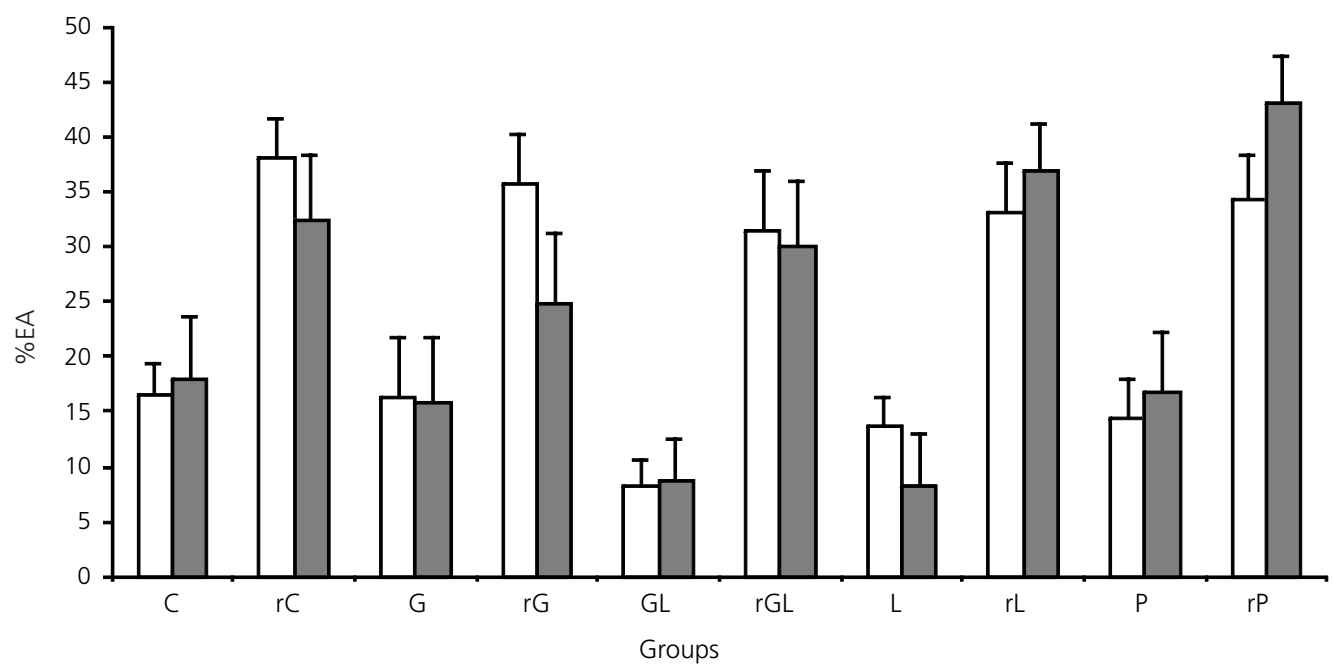

B

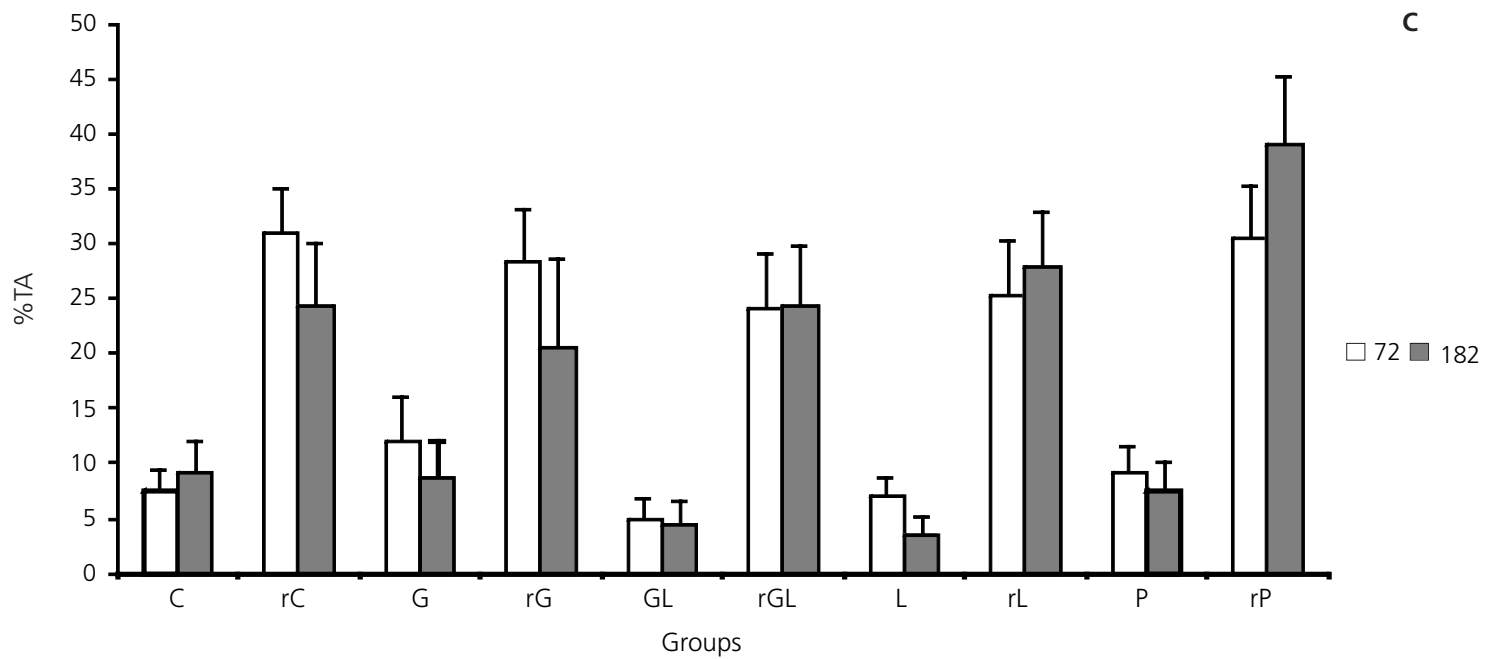

Figure 2. Latency of first entry (Part A), \% of entry (Part B), \% of time (Part C) and frequency of visits to the extremity (Part D) of the open arms of the Elevated Plus-Maze by animals at 72 and 182 days. 


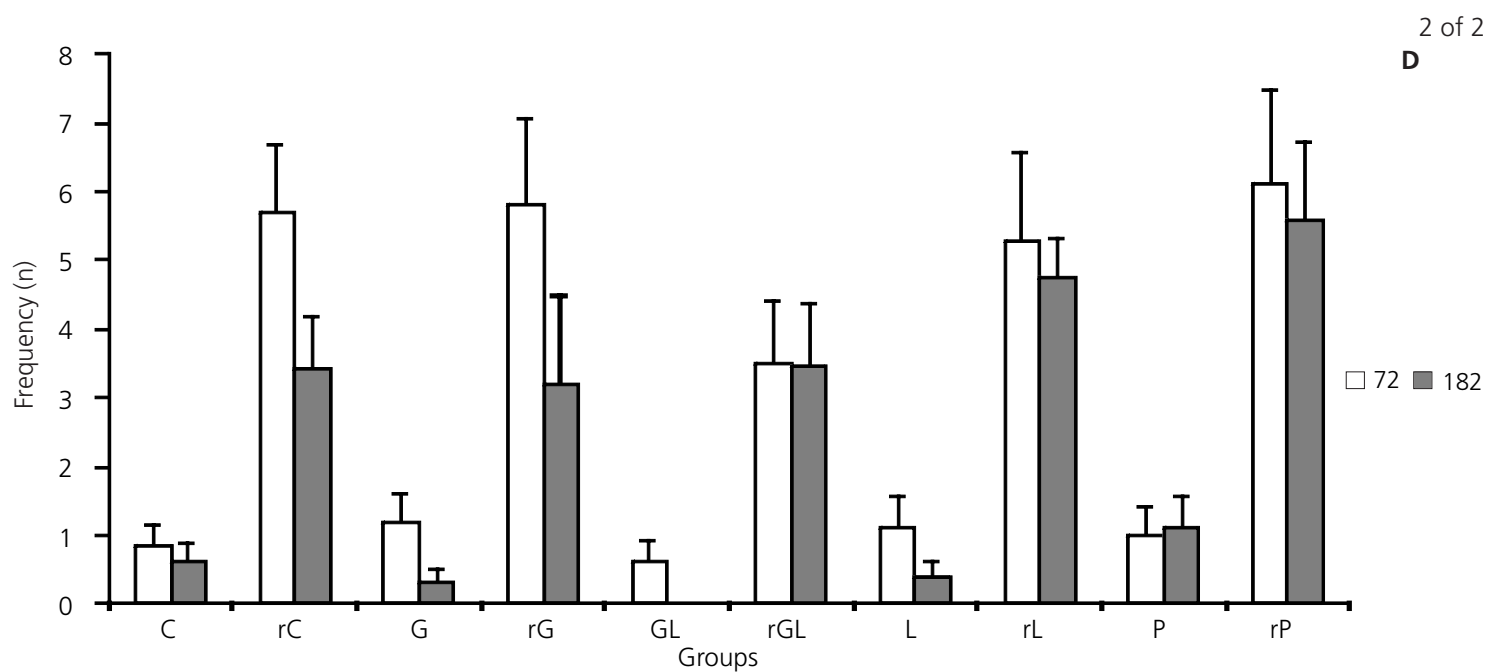

Figure 2. Latency of first entry (Part A), \% of entry (Part B), \% of time (Part C) and frequency of visits to the extremity (Part D) of the open arms of the Elevated Plus-Maze by animals at 72 and 182 days.

Note: C: Control; G: Carbohydrate; GL: Carbohydrate and Lipid; L: Lipid; rC: Control Restriction; rG: Carbohydrate Restriction; rGL: Carbohydrate and Lipid Restriction; rL: Lipid Restriction; rP: Protein Restriction.

Parts A, B, C and D: rC, rG, rGL, rL, rP>C, G, GL, L, P; Part A: 182>72; Part D: 72>182, by the Newman-Keuls Test ( $p<0.05)$.
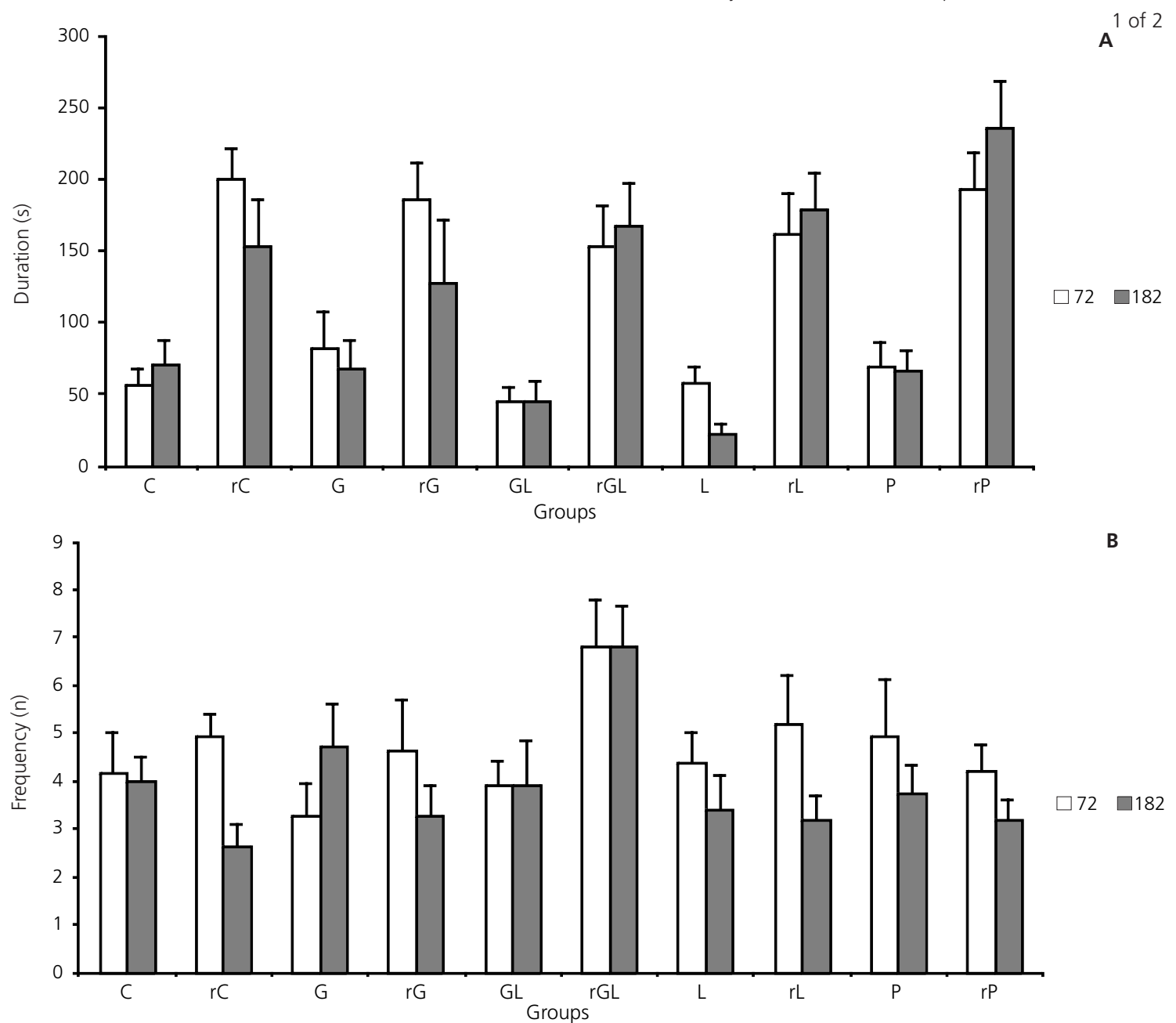

Figure 3. Duration in the central area (Part A), protected head dipping (Part B), unprotected (Part C) and total (Part D) in the Elevated Plus-Maze by animals at 72 and 182 days. 

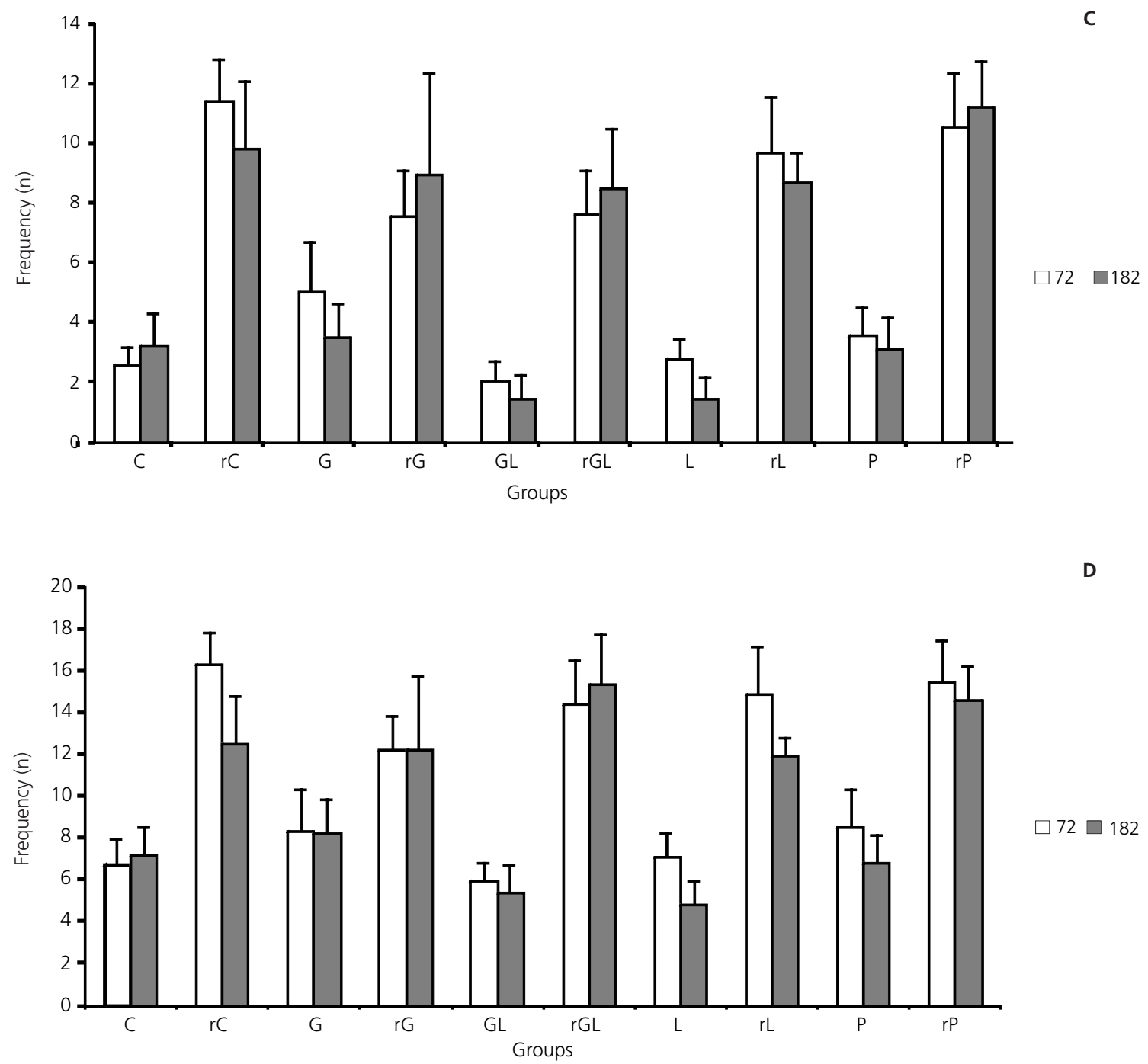

Figure 3. Duration in the central area (Part A), protected head dipping (Part B), unprotected (Part C) and total (Part D) in the Elevated Plus-Maze by animals at 72 and 182 days.

Note: C: Control; G: Carbohydrate; GL: Carbohydrate and Lipid; L: Lipid; rC: Control Restriction; rG: Carbohydrate Restriction; rGL: Carbohydrate and Lipid Restriction; rL: Lipid Restriction; rP: Protein Restriction.

Parts A, B, C and D: rC, rG, rGL, rL, rP> C, G, GL, L, P; Part B: 72>182, by the Newman-Keuls Test $(p<0.05)$.

Food restrictions for all groups increased the length of stay in the central area $\left(F_{(9.210)}=13.90\right.$, $p<0.0001)$ (Figure $3 A)$, the frequency of protected head dipping $\left(F_{(9.210)}=2.83, p<0.005\right)$ (Figure 3B), unprotected head dipping $\left(F_{(9.209)}=10.83, p<0.0001\right)$ (Figure $3 C$ ) and total head dipping $\left(F_{(9.209)}=9.21\right.$, $p<0.0001$ ) (Figure 3D). The 72-day-old animals showed a higher frequency of protected head dipping $\left(F_{(1.210)}=5.13, p<0.05\right)$ (Figure 3B) and false entries in the open arms $\left(F_{(1.207)}=17.18, p<0.0001\right)$ than the animals with 182 days of life (Figure 4A).

Regarding rearing, animals at 72 days were more frequently rearing than those at 182 days of life $\left(F_{(1.210)}=26.43, p<0.0001\right)$. There was also an interaction effect between diet and age $\left(F_{(9.210)}=2.23\right.$, $p<0.05)$, with the animals in the GL group that exhibited a higher rearing frequency at 182 than at 72 days of life (Figure 4B). 

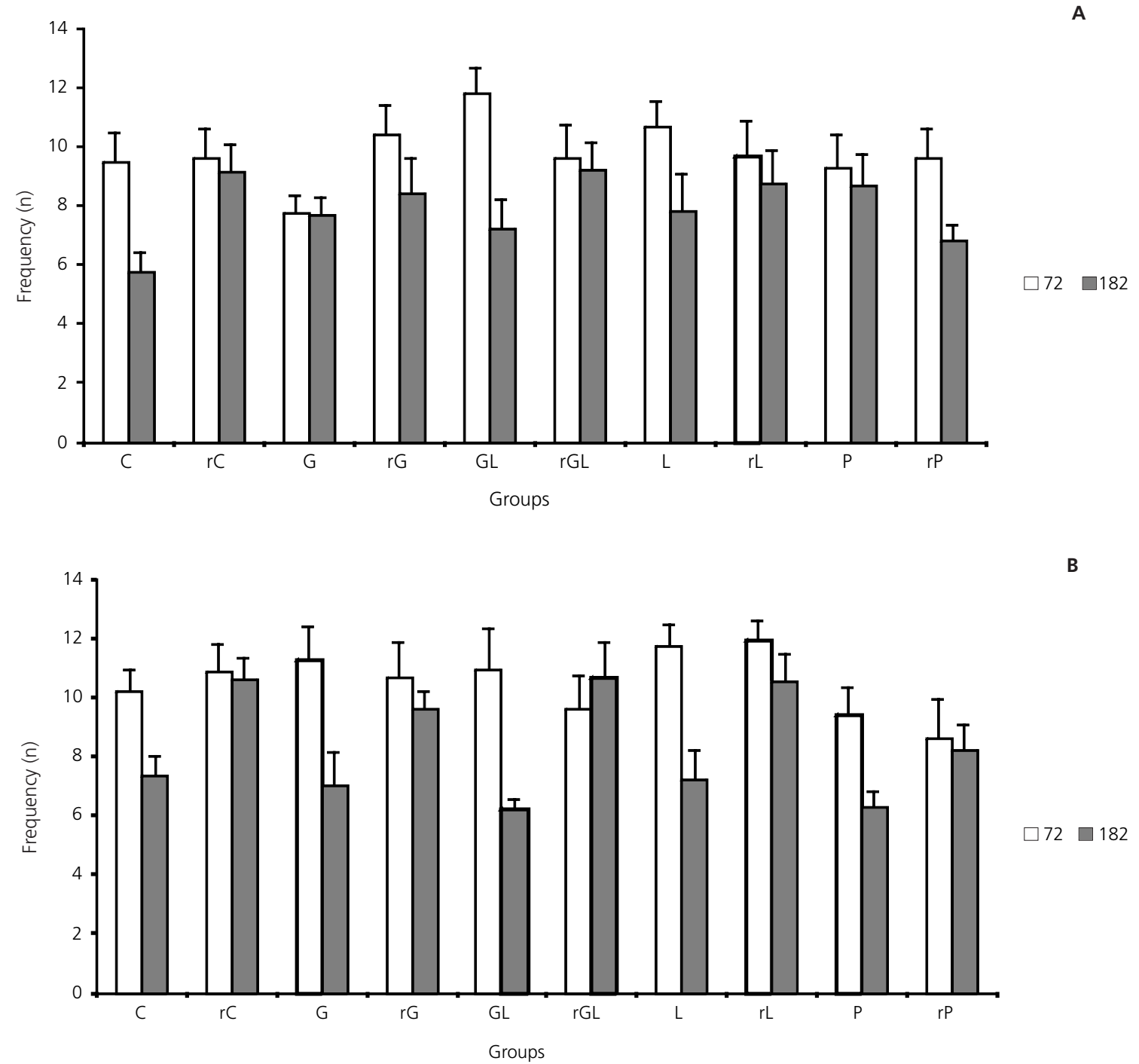

Figure 4. Frequency of false entries (Part A) and rearing (Part B) in the Elevated Plus-Maze by animals aged 72 and 182 days.

Note: C: Control; G: Carbohydrate; GL: Carbohydrate and Lipid; L: Lipid; rC: Control Restriction; rG: Carbohydrate Restriction; rGL: Carbohydrate and Lipid Restriction; rL: Lipid Restriction; rP: Protein Restriction.

Parts A and B: $72>182$, by the Newman-Keuls Test $(p<0.05)$.

\section{DISCUSSION}

Data consistency on the shortening of the first entry latency and the increase in the \% of entries, \% of time and frequency of visits to the extremities of the open arms, head dipping and time in the central area of the EPM, demonstrate that the animals that had undergone moderate and chronic food restriction (from birth to the age of 72 or 182 days) were less anxious and/or more impulsive than those who received an ad libitum diet.

These data suggest that moderate chronic food restriction, as well as moderate food restriction for a short period (3 weeks [25]) or fasting for a single night [27], which is an insufficient time to cause malnutrition, also demonstrated an anxiogenic effect, i.e., the same effect on anxiety behavior caused by severe malnutrition $[29,30]$. 
Another explanation for these results is that an adaptive behavior to the limited food setting occurred in animals under food restriction, leading them to enhance exploration of the maze, in an attempt to find food, even if the maze's open arms are aversive.

In fact, the animals in food restriction ate all the food in a few hours, and at the time of the test they were deprived of food and the greater exploration of the open arms could mean the search for food; however, it was expected that the animals would also enter more in the closed arms and this happened only for the $r G, r G L$ and rP groups.

On the other hand, in an experiment with severe restriction for 2 months [24] there was no effect on the anxiety test using the EPM. In contrast, other trials using moderate restriction that started 2 weeks before mating until the 20th day of gestation and the test performed with the pups in adult life [28], for 11 days [26], severe restriction for 5 days during pregnancy [30] demonstrated an anxiogenic effect.

One of the mechanisms that can explain alterations in the anxiety levels is the hypothesis of monoamines and glucocorticoids imbalance in the central nervous system. Literature data showed that anxiety symptoms decreased after treatment for weight loss (dietary restriction) that reduced serotonin and dopamine concentrations [31] and increased corticosterone in rats [32].

Food restriction can induce an activation of the Hypothalamic-Pituitary-Adrenal (HPA) axis, which is one of the main pathophysiological changes observed in patients suffering from mood and anxiety disorders and, since the hypothalamus is involved in the regulation of the HPA axis activity, it is believed that dysregulation of monoamines neurotransmission in the hypothalamus is involved in anxiety [31].

The lack of treatment effect among animals that were offered different types of diets ad libitum and among animals offered different types of diet in restricted quantities indicates that nutrients (protein, carbohydrate and/or lipid) did not interfere in the behavior of the animals assessed in the EPM, despite data in the literature showing that sucrose and lipids altered responses to stress on the HPA axis [33].

Despite the animals in groups $P$ and especially those in group $G$ showing less weight gain after 72 or 182 days treatment, the behavior in EPM was similar to animals in groups C, GL and L. These data match those in the literature when animals were treated with a diet rich in sucrose $[5,6]$, rich in protein $[20]$ and rich in lipids $[7,9,10,16]$ and also showed no change when tested in the EPM. However, the diet rich in lipids had an anxiolytic [13] and anxiogenic effect $[11,12,14,15,17]$. The diet rich in carbohydrates and lipids (cafeteria or western diet) also caused an anxiogenic effect $[18,19]$.

A hypothesis to explain the lower weight gain for animals in groups $P, G$ and $r G$ is the existence of a mechanism in the central nervous system that controls weight gain, reducing the intake of carbohydrates (more intense) and proteins (less intense) (data not shown) actually more important than the caloric content of the diets and sufficient to cause changes in the animals' body weight.

The greater latency for the first entry into the open arms and the reduced frequency of entry into the closed arms, false entries and visits to the end of the open arms, rearing as well as protected head dipping by the animals at 182 days, show that adults are more anxious and move around less than young adults. These data are consistent with those in the literature [34]. It is likely that structural changes, as well as the production of neurotransmitters and hormones, that occur during development, are responsible for the increased anxiety with aging. 
Great care is needed when recommending dietary restriction, even if moderate, especially for individuals during the growth and development phases while we are not sure of the beneficial and adverse effects of this feeding practice. Further studies are needed to assess the impact of macronutrients in the behavior and health, in general.

\section{CONCLUSION}

Food restriction caused a reduction in anxiety and/or an increase in impulsivity; aging resulted in an enhancement of anxiety and/or a reduction in impulsivity, and macronutrients did not affect animals' behavior in the EPM. Further studies are needed to better understand the mechanisms involved in the consumption of macronutrients, production of neurotransmitters, alterations in the HPA axis and in anxious behavior.

\section{ACNOWLEDGEMENTS}

We are grateful to RF MAZZEI and B OLIVEIRA for their technical support.

\section{CONTRIBUTORS}

TR RIUL contributed of the conception and design, analysis and interpretation of data, review and final approval of the article and SS ALMEIDA contributed of the conception and design, review and final approval of the article.

\section{REFERENCES}

1. United Nations Children's Fund. Levels and trends in child malnutrition: key findings of the 2018 Edition of the Joint Child Malnutrition Estimates. Geneva: World Health Organization; 2018 [cited 2018 Jul 18]. Available from: http://www.who.int/ nutgrowthdb/2018-jme-brochure.pdf?ua=1\&ua=1

2. Felberg EFB, Pinheiro MN, Batista EC. Psychological and social factors associated with child malnutrition: a bibliographical study. Rev Opara: Ciênc Contempor Aplic. 2016;6(1):32-48.

3. Herman MA, Samuel VT. The sweet path to metabolic demise: fructose and lipid synthesis. Trends Endocrinol Metabol. 2016;27(10):719-30. http://dx.doi.org/10.1016/j.tem.2016.06.005

4. Bartlett AA, Singh R, Hunter RG. Anxiety and epigenetics. In: Delgado-Morales R. Neuroepigenomics in aging and disease. New York: Springer; 2017. p.145-66. http://dx.doi.org/10.1007/978-3-319-53889-1_8

5. Apryatin SA, Shipelin VA, Sidorova YS, Petrov NA, Gmoshinskii IV, Nikityuk DB. Interspecific differences in behavioral responses and neuromotorics between laboratory rodents receiving rations with easily digested carbohydrates. Bull Exp Biol Med. 2018;165(1):9-14. http:/dx./doi.org/10.1007/s10517-018-4086-x

6. Rebolledo-Solleiro D, Roldán-Roldán G, Díaz D, Velasco M, Larqué C, Rico-Rosillo G, et al. Increased anxiety-like behavior is associated with the metabolic syndrome in non-stressed rats. Plos One. 2017;12(5):e0176554. https://dx.doi.org/10.1371/journal. pone.0176554

7. Chen Z, Xu Y-Y, Wu R, Han Y-X, Yu Y, Ge JF, et al. Impaired learning and memory in rats induced by a high-fat diet: involvement with the imbalance of nesfatin-1 abundance and copine 6 expression. J Neuroendocrinol. 2017;29(4):1-12. http://dx.doi.org/10.1111/jne.12462

8. Décarie-Spain L, Sharma S, Hryhorczuk C, Issa-Garcia V, Barker PA, Arbour N, et al. Nucleus accumbens inflammation mediates anxiodepressive behavior and compulsive sucrose seeking elicited by saturated dietary fat. Mol Metab. 2018;10:1-13. http://dx.doi.org/10.1016/j.molmet.2018.01.018 
9. Rio DD, Morales L, Ruiz-Gayo M, Olmo ND. Effect of high-fat diets on mood and learning performance in adolescent mice. Behav Brain Res. 2016;311:167-72. http://dx.doi.org/10.1016/j.bbr.2016.04.052

10. Hryhorczuk C, Décarie-Spain L, Sharma S, Daneault C, Rosiers CD, Alquier T, et al. Saturated high-fat feeding independent of obesity alters hypothalamuspituitary-adrenal axis function but not anxiety-like behaviour. Psychoneuroendocrinology. 2017;83:142-9. http://dx.doi.org/10.1016/j.psyneuen.2017.06.002

11. Kaur T, Kaur G. Withania somnifera as a potential candidate to ameliorate high fat diet-induced anxiety and neuroinflammation. J Neuroinflamm. 2017;14:201-19. http://dx.doi.org/10.1186/s12974-017-0975-6

12. Kurhe Y, Mahesh R, Devadoss T. Novel 5-HT3 receptor antagonist QCM-4 attenuates depressive-like phenotype associated with obesity in high-fat-diet-fed mice. Psychopharmacology. 2017;234:1165-79. http://dx.doi.org/10.1007/s00213-017-4558-0

13. McNeilly AD, Stewart CA, Sutherland C, Balfour DJK. High fat feeding is associated withstimulation of thehypothalamic-pituitary-adrenal axis andreduced anxiety in the rat. Psychoneuroendocrinology. 2015;52:272-80. http://dx.doi.org/10.1016/j.psyneuen.2014.12.002

14. Park H-S, Lee J-M, Cho H-S, Park S-S, Kim T-W. Physical exercise ameliorates mood disorder-like behavior on high fat dietinduced obesity in mice. Psychiatry Res. 2017;250:71-7. http://dx.doi.org/10.1016/j. psychres.2017.01.012

15. Romero-Zerbo SY, Ruz-Maldonado I, Espinosa-Jiménez V, Rafacho A, Gómez-Conde Al, Sánchez-Salido L, et al. The cannabinoid ligand LH-21 reduces anxiety and improves glucose handling in diet-induced obese pre-diabetic mice. Sci Rep. 2017;7:3946-59. http://dx. doi.org/10.1038/s41598-017-03292-w

16. Takase K, Tsuneoka Y, Oda S, Kuroda M, Funato H. High-fat diet feeding alters olfactory-, social-, and reward-related behaviors of mice independent of obesity. Obesity. 2016;24:886-94. http://dx.doi. org/10.1002/oby.21441

17. Yang JL, Liu DX, Jiang H, Pan F, Ho CSH, Ho RCM. The effects of high-fat-diet combined with chronic unpredictable mild stress on depression-like behavior and Leptin/LepRb in male rats. Sci Rep. 2016;6:35239-51. http://dx.doi.org/10.1038/srep35239

18. Kalyan-Masih P, Vega-Torres JD, Miles C, Haddad E, Rainsbury S, Baghchechi M. Western high-fat diet Consumption during adolescence increases susceptibility to traumatic stress while selectively disrupting hippocampal and ventricular volumes. Eneuro. 2016;3(5):1-24. http://dx.doi.org/10.1523/ ENEURO.0125-16.2016

19. Warneke W, Klaus S, Fink H, Langley-Evans SC, Voigt J-P. The impact of cafeteria diet feeding on physiology and anxiety-related behaviour in male and female Sprague-Dawley rats of different ages. Pharmacol Biochem Behav. 2014;116:45-54. http://dx.doi.org/10.1016/j.pbb.2013.11.01

20. Méndez-López M, Méndez M, Arias J, Arias JL. Effects of a high protein diet on cognition and brain metabolism in cirrhotic rats. Physiol Behav. 2015;149:220-8. http://dx.doi.org/10.1016/j.physbeh.2015.05.038

21. Eissenberg JC. Hungering for immortality. Perspective. 2018;115(1):12-7.

22. Mitchell SJ, Bernier M, Mattison JA, Anderson RM, Ingram DK, Cabo R. Daily fasting improves health and survival in male mice independent of diet composition and calories. Cell Metabolism. 2018;28:1-8. http:// dx.doi.org/10.1016/j.cmet.2018.08.011

23. Pifferi F, Terrien J, Marchal J, Dal-Pan A, Djelti F, Hardy I, et al. Caloric restriction increases lifespan but affects brain integrity in grey mouse lemur primates. Comm Biol. 2018. http://dx.doi.org/10.1038/s42003-018-0 024-8

24. Cardoso A, Marrana F, Andrade JP. Caloric restriction in young rats disturbs hippocampal neurogenesis and spatial learning. Neurobiol Learn Mem. 2016;133:214-24. http://dx.doi.org/10.1016/j.nlm.2016.07.013

25. Kenny R, Dinan T, Cai G, Spencer SJ. Effects of mild calorie restriction on anxiety and hypothalamic-pituitaryadrenal axis responses to stress in the male rat. Physiol Rep. 2014;2(3):e00265. http://dx.doi.org/10.1002/ phy2.265

26. Govic A, Bell V, Samuel A, Penman J, Paolini AG. Calorie restriction and corticosterone elevation during lactation can each modulate adult male fear and anxiety-like behaviour. Horm Behav. 2014;66:591-601. http://dx.doi.org/10.1016/j.yhbeh.2014.08.013

27. Maniscalco JW, Zheng H, Gordon PJ, Rinaman L. Negative energy balance blocks neural and behavioral responses to acute stress by "silencing" central glucagon-like peptide 1 signaling in rats. J Neurosci. 2015;35(30):10701-14. http://dx.doi.org/ 0.1523/JNEUROSCI.3464-14.2015 
28. Ramírez-López MT, Vázquez M, Bindila L, Lomazzo E, Hofmann C, Blanco RN, et al. Maternal caloric restriction implemented during the preconceptional and pregnancy period alters hypothalamic and hippocampal endocannabinoid levels at birth and induces overweight and increased adiposity at adulthood in male rat offspring. Front Behav Neurosci. 2016;10:208. http://dx.doi.org/ 10.3389/fnbeh.2016.00208

29. Soares RO, Rorato RC, Padovan D, Lachat JJ, Antunes-Rodrigues J, Elias LK, et al. Environmental enrichment reverses reduction in glucocorticoid receptor expression in the hippocampus of and improves behavioral responses of anxiety in early malnourished rats. Brain Res. 2015;1600:32-41. http://dx.doi.org/10.1016/j. brainres.2014.12.047

30. Hino K, Kimura T, Udagawa J. Handling has an anxiolytic effect that is not affected by the inhibition of the protein kinase $C$ pathway in adult prenatal undernourished male rat offspring. Congenit Anom. 2019;1-8. http://dx.doi.org/10.1111/cga.12332

31. Perez-Cornago A, Ramírez MJ, Zulet MA, Martinez JA. Effect of dietary restriction on peripheral monoamines and anxiety symptoms in obese subjects with metabolic syndrome. Psychoneuroendocrinology. 2014;47:98-106. http://dx.doi.org/10.1016/j.psyneuen.2014.05.003

32. Levay EA, Tammer AH, Penman J, Kent S, Paolini AG. Calorie restriction at increasing levels leads to augmented concentrations of corticosterone and decreasing concentrations of testosterone in rats. Nutr Res. 2010;30:366-73. http://dx.doi.org/10.1016/j.nutres.2010.05.001

33. Sinha R. Role of addiction and stress neurobiology on food intake and obesity. Biol Psychol. 2018;131:5-13. http://dx.doi.or/10.1016/j.biopsycho.2017.05.001

34. Perna G, lannone G, Alciati A, Caldirola D. Are anxiety disorders associated with accelerated aging: a focus on neuroprogression. Neural Plast. 2016;1-19. http://dx.doi.org/10.1155/2016/8457612 